\title{
PRE-SERVICE STUDENTS' TRAINING TO TEACH LISTENING IN THE ENGLISH LANGUAGE CLASSROOM
}

Gembaruk Alla, Ph.D. in Education, Associate Professor, Pavlo Tychyna Uman State Pedagogical University.

ORCID: 0000-0001-8135-0800

E-mail: gembaruk.alla@gmail.com

The article describes the way of pre-service students' training to teach listening in the English language classroom which is done within the framework of new PRESETT Curriculum on Methodology designed in context of "New Generation School Teachers" joint project (2013-2019), initiated by the Ministry of Education and Science, Ukraine and the British Council, Ukraine. The article highlights the content of the unit devoted to teaching listening, its structure, modes of teaching and learning, assessment specifications. The article also specifies the tasks for school experience and the way teacher assistantship is organized. The results of students' evaluation of the unit on teaching listening are presented in the article.

Keywords: PRESETT Curriculum on Methodology, "New Generation School Teachers" project, preservice teacher training, teaching listening, school experience, modes of teaching and learning, assessment specifications, reflection, unit evaluation form, self-assessment checklist.

\section{ПІДГОТОВКА СТУДЕНТІВ ДО НАВЧАННЯ АУДІЮВАННЯ НА УРОКАХ АНГЛІЙСЬКОЇ МОВИ}

Гембарук Алла, кандидат педагогічних наук, доцент, Уманський державний педагогічний університет імені Павла Тичини.

ORCID: 0000-0001-8135-0800

E-mail: gembaruk.alla@gmail.com

У статті описано систему підготовки студентів до навчання аудіювання на уроках англійської мови в школі, щьо здійснюється відповідно до нової навчальної програми «Методика навчання англійської мови», розробленої у межах спільного проекту "Шкільний вчитель нового покоління» (2013-2019) Міністерства освіти і науки Украӥни та Британської Ради в Україні. Представлено опис змістового модуля 3.1 Навчання аудіювання, який відповідно до програми вивчається у V семестрі. Детально описано зміст модуля, його структуру, режими викладання та навчання, специфікації оцінювання, завдання для педагогічної практики та иляхи ї̈ організації. Представлена мапа змістового модуля окреслює його орієнтовну тематику та ї розподіл у межах навчальних занять. Опис модуля містить формулювання иілей $і$ результатів учіння, а також рекомендоване контрольне завдання та критерії його оцінювання. План навчального заняття з теми «Аудіювання як вид мовленнєвої діяльності», який подано у статті, наочно демонструє інтерактивний підхід до викладання змісту модуля, щзо базується на приниипі «до теорї через практику», відповідно до якого студенти опановують новий матеріал, вирішуючи різноманітні завдання в парах чи мікрогрупах, діляться власним досвідом та рефлексують, що в свою чергу сприяє їхньому професійному розвитку. Описано систему організації педагогічної практики в школі, яка інтегрована у курс методики і відбувається один раз на тиждень (мінімум чотири години) з відривом від освітнього процесу в ЗВО. Зазначено, щуо під час перебування в школі студенти не лише спостерігають за роботою досвідчених учителів, а й планують фрагменти занять з навчання аудіювання та апробують ӥх на уроках англійської мови. Також представлено результати оцінювання змістового модуля «Навчання аудіюванню» 


\begin{abstract}
студентами III курсу факультету іноземних мов ОС «Бакалавр», яке базувалося на таких засобах діагностики, як анкетування, щьо здійснювалося иляхом письмових відповідей респондентів на систему стандартизованих запитань спеціально розробленої форми оиінювання змістового модуля, та заповнення форми самооцінювання результатів учіння. Результати анкетування засвідчили ефективність змістового модуля 3.1 Навчання аудіювання. Ключові слова: навчальна програма з методики навчання англійської мови, проект «Шкільний вчитель нового покоління», додипломна підготовка вчителів, навчання аудіювання, педагогічна практика, форми навчання, специфікації оцінювання, рефлексія, форма оцінювання змістового модуля, форма самооцінювання результатів учіння.
\end{abstract}

The Ukrainian education system has been in a state of transition ever since independence. However, the last six years have been the most crucial for since important new laws on education have been passed. The New Ukrainian School is a key reform of the Ministry of Education and Science. The main objective of it is to create a school that will be pleasant to go to and will provide the students not only with knowledge, but also with the ability to apply it in real life [8].

Nevertheless, no changes are possible without a personality of a teacher, so the New Ukrainian School requires a new teacher, a teacher of new generation. "New Generation School Teacher" joint project (2013-2019), initiated and supported by the Ministry of Education and Science of Ukraine and the British Council Ukraine, has introduced change in the initial teacher training system of Ukraine long before the New Ukrainian School reform. The work on the project resulted in designing and implementing a new PRESETT Curriculum on Methodology for the initial EFL teacher training system in Ukraine [1]. Being based on the best Ukrainian and world practices in EFL teacher training, the new Curriculum represents a significant change in the way English teachers are educated.

As it is mentioned in the article EFL Teachers Training in Pavlo Tychyna Uman State Pedagogical University: Methodological Aspect (A, Gembaruk (2019)) teacher training according to the PRESETT Curriculum starts in Year 2 and lasts for three years. The total number of hours allocated to the whole course is 660, where 396 hours are contact and the rest 264 hours are self-study. That makes the methodology course a core subject in EFL teacher education. Since methodology is delivered in English, it promotes the development of language proficiency level as well as the level of professional communication. Besides, students undertake school practice throughout the whole methodology course. The Curriculum specifies a total of 17 credits for school experience. Another distinguishing feature of the PRESETT Curriculum is approaches to teaching and learning. Having refused from lecturing as an inefficient way of delivering content, new methodology relies on innovative teaching and learning approaches including task-based learning, the use of case studies, simulations, group projects and problem solving. All of these approaches are intended to promote high levels of interaction and student involvement in their own learning processes. The Curriculum consists of 6 modules. Each module represents a broad area of methodology, and contains a number of units, 22 in all. Each unit covers an essential specialist topic for English teachers in training [4].

The purpose of the present article is to analyse the process of pre-service students' training to teach listening in the English language classroom according to the new PRESETT Curriculum on Methodology and to evaluate its effectiveness.

Of four language skills, reading, writing, speaking and listening, R, Oxford (1993) considers listening to be the "most fundamental" [6]. According to one estimate, humans typically "spend 70 to 80 percent of our waking hours in some form of communication. Of 
that time, we spend about 9 percent writing, 16 percent reading, 30 percent speaking, and 45 percent listening" [5]. This data indicates the important role of listening comprehension in the learning process. On the other hand, being able to listen well is crucial to workplace communication skills in any job role. Great listening skills will allow performing better, communicating more effectively, understanding more, and feeling like a part of the team [7]. Consequently, R, Oxford (1993) affirms that skill of listening should be a major area of concern to teachers and students of a second or foreign language [6]. Following her point of view, we think that teachers should pay more attention to developing listening skills; they must be equipped with a range of techniques to teach listening effectively. In this perspective, pedagogical universities are to improve pre-service students' training to their work at school. The new PRESETT Curriculum on Methodology which is currently being implemented in more than 14 Ukrainian universities includes special unit on teaching listening - Unit 3.1 Teaching Skills - Teaching Listening - which trains pre-service students to teach this skill to ESL learners. In this article, we will analyse Unit 3.1 in terms of its content, structure, modes of teaching and learning, assessment specifications; and provide students' evaluation of it. This aim may be realized by applying the corresponding methods: analysis to gain a better understanding of Unit 3.1 Teaching Skills - Teaching Listening; survey to evaluate the effectiveness of the Unit content in EFL teacher training.

The following key findings emerged from the analysis of Unit 3.1 of the new PRESETT Curriculum on Methodology [1, pp. 50-54].

Unit 3.1 Teaching Skills - Teaching Listening comes first in Module 3. Preparing to teach 2. According to the Curriculum this unit is studied in Year 3, Semester 5. The total number of hours allocated to the unit is 30, where 18 hours are contact and the rest 12 hours are self-study. The objectives of the unit are shaped in the way, that by the end of this unit students will be aware of: curriculum requirements for teaching listening; psychological and phonological features of speech perception; the importance of listening as a skill underpinning all the other skills; listening subskills; listening task sequences; types of listening materials. They also will be able to: anticipate possible learners' problems in listening and suggest ways of solving them; use strategies and activities for developing learner listening skills according to the purpose of listening; assess learners' listening skills and give feedback to learners on their achievements; evaluate, select and adapt listening materials; teach listening at different language proficiency levels; plan a sequence of activities that focus on developing listening skills.

The content of Unit 3.1 Teaching Skills - Teaching Listening is designed to meet these objectives. Table 1 provides sample unit map, which covers its major topics.

Table 1

Sample Unit Map

\begin{tabular}{|c|l|}
\hline Session & \multicolumn{1}{c|}{ Content } \\
\hline & Listening as a skill \\
& An overview of different types of listening materials: \\
• coursebook recordings \\
1 & • videos \\
& $\bullet$ podcasts \\
& $\bullet$ online resources \\
& The primacy of listening \\
& The importance of exposure to authentic listening inputs \\
\hline
\end{tabular}




\begin{tabular}{|c|c|}
\hline 2 & $\begin{array}{l}\text { Difficulties learners may face while listening } \\
\text { Curriculum requirements for teaching listening to different age groups } \\
\text { Listening in the CEFR }\end{array}$ \\
\hline 3 & $\begin{array}{l}\text { The place of phonology in teaching listening } \\
\text { Intonation, stress, rhythm and their functions } \\
\text { Anticipated phonological difficulties: } \\
\text { - weak forms } \\
\text { - contractions } \\
\text { - elision } \\
\text { - word and sentence stress patterns } \\
\text { Teaching techniques for dealing with phonological difficulties: } \\
\text { - minimal pairs/trios } \\
\text { - TPR } \\
\text { - recognition of function } \\
\text { - recognition of attitude }\end{array}$ \\
\hline 4 & $\begin{array}{l}\text { Different purposes for listening } \\
\text { - listening for gist } \\
\text { - listening for detail/intensive listening } \\
\text { - listening for specific information } \\
\text { Ways in which people listen for each purpose }\end{array}$ \\
\hline $5-6$ & $\begin{array}{l}\text { Key strategies for developing learners' listening skills: } \\
\text { - top-down } \\
\text { - bottom-up } \\
\text { - metacognitive }\end{array}$ \\
\hline 7 & $\begin{array}{l}\text { Activities for teaching listening skills } \\
\text { Sequencing activities }\end{array}$ \\
\hline 8 & Evaluation, selection and adaptation of listening materials \\
\hline 9 & Assessing learners' listening skills \\
\hline
\end{tabular}

The content presented in Table 1 is indicative, so each university can make any changes to both the content and its distribution within sessions. The only thing that matters is meeting the objectives and demonstrating the evidence of learning on the unit in terms of outcomes, which can be assessed. Assessment in Unit 3.1 consists of completing one of module assignments (Item 1) which states as follows:

For this task, your teacher will give you an audio text, and provide you with the information about the learners' age group, language proficiency level, and purpose for listening to address. Individually, develop a sequence of at least four activities to meet learners' needs and learning purpose. Provide rationale for the choice of activities and instructions for organising them in class.

Students are given grades according to the detailed criteria in the assessment specifications for each unit in the Curriculum. Table 2 presents assessment specifications for Item 1.

Table 2

\section{Assessment Specifications for Item 1}

\begin{tabular}{|l|c|}
\hline Assessment criteria & Weighting \\
\hline $\begin{array}{l}\text { Task fulfilment (all items are submitted: group profile, text transcript, a sequence of activities } \\
\text { with instructions) }\end{array}$ & $5 \%$ \\
\hline Evidence of the ability to develop a sequence of activities for the purpose of teaching listening & $5 \%$ \\
\hline Total & $\mathbf{1 0} \%$ \\
\hline
\end{tabular}

ISSN 2307-4914 
By doing this item students demonstrate the competences they acquired in the result of learning on Unit 3.1 Teaching Skills - Teaching Listening.

Competence-based content of the unit as well as the Curriculum itself is one of the distinguishing aspects of it. Being structured in such way, the Curriculum meets the requirements of Ukrainian education reform, the core idea of which is acquiring skills and abilities to obtain knowledge independently and apply it in practice [4]. Content delivery relies on innovative teaching and learning approaches, which include task-based learning, case studies, simulations, group projects, problem solving, discussions, microteaching, etc. All of these approaches are intended to promote high level of interaction and student involvement in their own learning processes, thus ensuring the development of necessary professional skills to teach listening to ESL learners.

The way content is delivered can be demonstrated on the example of Session 1 on Unit 3.1 Teaching Skills - Teaching Listening [2, pp. 10-17].

\section{Topic 1 Listening as a skill}

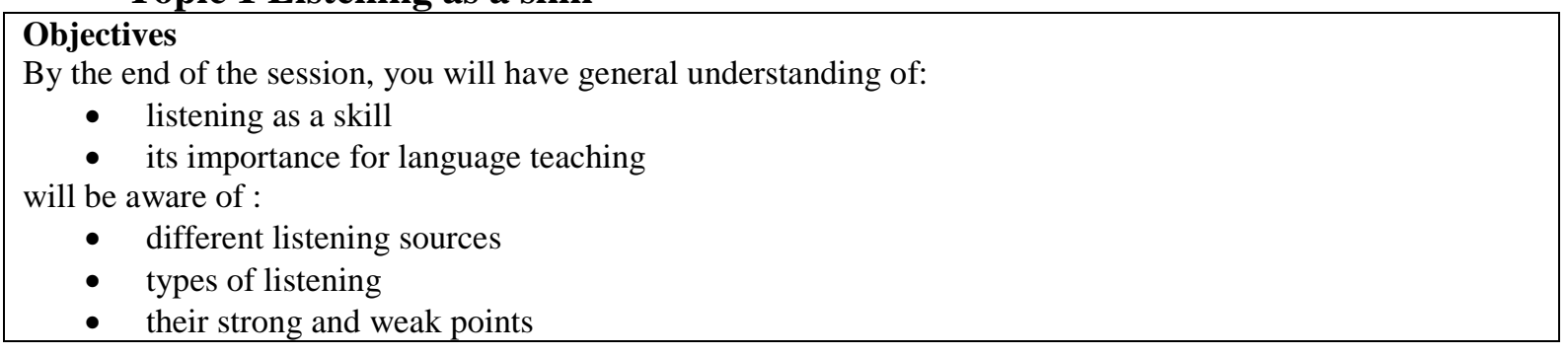

\subsection{Understanding listening}

Share your viewpoint on the questions below:

- How do you understand listening?

- What is meant by listening (skills)?

- Do hearing and listening mean the same things Why? or Why not?

Your teacher will demonstrate some definitions of listening for you to compare.

Read them and tell if your understanding of listening (skills) changed?

\subsection{Myths and truth about listening}

Working in pairs, read the statements and decide if they are myths or the truth, tick the relevant column. Justify your choice

\begin{tabular}{|l|l|l|l|}
\hline \multicolumn{1}{|c|}{ Statement } & Myth & Truth & Comments \\
\hline 1. Listening is a 'passive' skill & & & \\
\hline $\begin{array}{l}\text { 2. It is easier for students to understand native speakers of } \\
\text { English than foreign speakers of English }\end{array}$ & & & \\
\hline $\begin{array}{l}\text { 3. The skills involved in listening to a foreign language are } \\
\text { the same as those that we use for listening to our native } \\
\text { language }\end{array}$ & & & \\
\hline $\begin{array}{l}\text { 4. While listening in class, students shouldn't try to } \\
\text { understand every word. }\end{array}$ & & & \\
\hline $\begin{array}{l}\text { 5. Students shouldn't be allowed to read the scripts of } \\
\text { recordings. }\end{array}$ & & & \\
\hline
\end{tabular}




\section{Limited}

Available from: Wilson, J. J. (2008). How to Teach Listening. Pearson Education

Discuss your viewpoints with the whole group

\subsection{Different sources of listening}

Discuss the following questions and fill in the table below

- What do we listen to in learning a foreign language?

-Why do we listen?

- Where do we listen?

\begin{tabular}{|l|l|l|}
\hline What? & Why? & Where? \\
\hline & & \\
\hline
\end{tabular}

Discuss your viewpoints with the whole group

\subsection{Listening types}

Familiarize with J. J. Wilson's classification of Sources of Listening

- Teacher talk

- Student talk

- Guest speakers

- Textbook recordings

- Television, video, DVD and radio

- Songs

- The internet

Available from: Wilson, J. J. (2008). How to Teach Listening. Pearson Education Limited

Compare it with your version

Add the missed sources to the table you filled in

Categorise listening sources dividing them into two types: live listening and recorded listening. Fill in the table below:

\begin{tabular}{|l|l|}
\hline Live listening & Recorded listening \\
\hline & \\
\hline
\end{tabular}

\subsection{Advantages and disadvantages of listening types}

Define the advantages/benefits and disadvantages (if any) of one of the types of listening. Represent your ideas on the poster

Present your posters and justify your ideas.

Read J. J. Wilson's description of listening sources available from: Wilson, J. J. (2008) How to Teach Listening. Pearson Education Limited. P. 40-57. 
Add some more points to the suggested by you list of advantages or disadvantages.

Study the information and add some more points to the suggested by you list of advantages or disadvantages.

Discuss it in plenary.

\subsection{Reflection}

Name three things you find important for you.

(English Language Teaching Methodology: Module 3. Preparing to Teach 2).

The example of Session 1 clearly demonstrates the way learning is organized on "to theory through practice" approach. According to which students learn new ideas by having exposure to different problems and solving them either in pairs or in small groups. The interactive character of the sessions gives students a lot of opportunities to share their experience and to learn from each other. Much attention is paid to reflection, which is the key point of the new PRESETT Curriculum on Methodology. The final stage of each session is reflective stage. Individually or in groups, students reflect on what they have learnt, what they are well aware of and what still is not clear for them. We strongly believe that reflection promotes students' professional growth as teachers.

One more peculiar feature of the Curriculum is that all the methodology classes are closely linked to teaching at school. According to the timetable students have teacher assistantship once a week. During teacher assistantship, students do not only observe experienced teachers at their work, but also generally support English language teachers, plan lessons together with their mentors and even try their hand at teaching parts of a lesson. Teacher assistantship is provided with tasks recommended by the new PRESETT Curriculum on Methodology [3]. Incorporating school experience into methodology classes develops teachers' competence in an actual classroom within school settings.

To evaluate the effectiveness of pre-service students' training to teach listening at school the third year students were given an anonymous survey. A total of 46 participants were recruited for this survey. They were asked to fill in Unit evaluation form and selfassessment checklist. Unit evaluation form included questions that were supposed to provide information on what students enjoyed most about the unit; they were also asked to specify anything they did not understand; to analyse the suggested materials in terms of userfriendliness. The next question was targeted at getting information on what students learnt during the unit that they anticipate using in their work. We were also interested in the most valuable things students learned and in other specific comments if any.

The major part of the answers was positive and showed students' real attitude to their learning on Unit 3.1 Teaching Skills - Teaching Listening. Having analysed the information on what students enjoyed most about the unit we identified some similar aspects. Among them: interactive, communicative, informative and practical character of the sessions. Some of the students most of all liked the sessions devoted to listening strategies; stages of the listening lesson; tasks and activities for teaching listening and their sequencing. They consider these aspects very important for them both as students and as would-be teachers. Students 
also appreciated watching videos, commenting on metaphors of two different listening purposes, composing a teacher planning kit on teaching listening, etc. In their opinion, such activities develop creativity and critical thinking, the skills that are very important for their future work.

As for the areas that caused difficulty or misunderstanding, students mentioned the following: selection and adaptation of listening materials for different learning purposes; listening strategies and their classroom implication. However, the majority of the students didn't see a big problem here as they could always ask their teachers for additional explanation or study them more thoroughly by themselves. Nevertheless, these particular areas require further consideration on teachers' part.

All the students were unanimous in answering the third question of Unit evaluation form and admitted that the suggested materials were user-friendly.

Speaking about the things students learnt during the Unit that they anticipate using in their future work, all of them find all the topics very useful. What they really appreciate is "Teacher Planning Kit" they designed. In students' opinion, it is of utmost importance for them as future teachers.

When asked about most valuable things they learnt, all the participants named both knowledge and skills they got in the result of learning on the unit as these two things provide their teaching experience.

Other specific comments given by the students outlined their needs, among them were more references recommended for further reading and more practice. These comments are of special value for us as they include constructive ideas for improving the unit.

Another tool suggested for evaluating the effectiveness of Unit 3.1 Teaching Skills Teaching Listening was self-assessment checklist which students were asked to fill-in after learning the unit. Self-assessment checklist is given in Table 3.

Table 3

\section{Self-assessment checklist on Unit 3.1 Teaching Skills - Teaching Listening}

\begin{tabular}{|l|l|l|l|}
\hline \multicolumn{1}{|c|}{ Now that I have completed this Unit, I can } & $\begin{array}{c}\text { without } \\
\text { difficulty }\end{array}$ & $\begin{array}{c}\text { to some } \\
\text { extent }\end{array}$ & not at all \\
\hline $\begin{array}{l}\text { evaluate, select and adapt listening materials for different } \\
\text { learning purposes }\end{array}$ & & & \\
\hline - $\begin{array}{l}\text { make suggestions to solve the problems which learners face in } \\
\text { listening }\end{array}$ & & & \\
\hline - $\begin{array}{l}\text { develop listening activities according to learners' needs and } \\
\text { different listening purposes }\end{array}$ & & & \\
\hline - $\begin{array}{l}\text { prepare a part of a lesson with activities focusing on } \\
\text { developing listening skills }\end{array}$ & & & \\
\hline $\begin{array}{l}\text { assess learners' listening skills and give feedback to learners } \\
\text { on their achievement }\end{array}$ & & & \\
\hline
\end{tabular}

The answers of the third year students revealed that half of them (50\% of the group of survey participants) can evaluate, select, and adapt listening materials for different learning purposes without difficulty and $50 \%$ can do it to some extent. The same data was got on students' ability to make suggestions to solve the problems that learners face in listening. 
Almost $66 \%$ of the respondents can develop listening activities according to learners' needs and different listening purposes without difficulty. Only $34 \%$ of them can do it to some extent. $63.7 \%$ of survey participants admitted that they can prepare a part of a lesson with activities focusing on developing listening skills without difficulty, while $36.3 \%$ of them still can do it to some extent. At the same time, $52.4 \%$ of the students think that they can assess learners' listening skills and give feedback to learners on their achievement without difficulty and $47.6 \%$ can do it to some extent. It was interesting to see that no one has ticked the option "not at all". Overall, the answers show that the students have acquired basic knowledge and necessary skills to teach listening to ESL learners. Though less than a half of the participants requires more teaching practice in order to become more experienced.

Thus, we can conclude that Unit 3.1 Teaching Skills - Teaching Listening corresponds to the requirements of the education reform in Ukraine. Due to well-designed structure, interactive modes of teaching and learning, clear assessment specifications, new procedure of teacher assistantship the unit provides good pre-service students' training to teach listening in the English language classroom. However, it requires some improvements by giving students more practice in designing lessons with the focus on listening. The third year students did the evaluation of the unit using such tools as Unit evaluation form and self-assessment checklist. Survey results proved the effectiveness of the unit.

The article does not exhaust all the aspects of the research problem. Some of the Unit sessions require more careful consideration. Therefore, further work in the chosen direction has a good chance to contribute to Unit improvement and making it more practically oriented.

\section{REFERENCES}

1. Bevz, O., Gembaruk, A., Goncharova, O., Zabolotnaa, O. et.al. (2020). Metodyka navchannya angliiskoi movy. Osvitniy stupin bakalavra: typova programa: Ivano-Frankivsk [in Ukrainian].

2. Bevz, O., Brit, N., Gembaruk, A. (2020). English Language Teaching Methodology: Module 3. Preparing to Teach 2: Student workbook. Uman: Vizavy.

3. Core Curriculum English Language Teaching Methodology: School Experience Observation Tasks. Module 3. URL: https://1fd10c7a-6813-41b3-98e8-e5598ca6cc9b.filesusr.com/ugd/15b470_75c5f4ceb 60d4d2ba30f35f52c2fe5d8.pdf

4. Gembaruk, A. S. (2019). EFL Teachers Training in Pavlo Tychyna Uman State Pedagogical University: Methodological Aspect. Studies in Comparative Education, 2 (38), 70-80.

5. Lee, D., Hatesohi, D. (1993). Listening: Our most used communication skill. URL: https://mospace. umsystem.edu/xmlui/bitstream/handle/10355/71861/CM150-1983.pdf?sequence=1

6. Oxford, R. (1993). Research update on teaching L2 listening. System, 21(2), 205-211. URL: http://onlinecourse.ncolctl.org/fundamentals/lesson5/downloads/L5_Oxford.pdf7. The importance of listening skills in the communication process. URL: https:/www.hrdqu.com/communication-styles/learning-tolisten-the-importance-of-great-communication-skills/

7. The New Ukrainian School Concept. URL: https://mon.gov.ua/eng/tag/nova-ukrainska-shkola

\section{СПИСОК ВИКОРИСТАНИХ ДЖЕРЕЛ}

1. Бевз О., Гембарук А., Гончарова О., Заболотна О. та ін. Методика навчання англійської мови. Освітній ступінь бакалавра: типова програма: Івано-Франківськ: НАІР, 2020. 126 с.

2. Bevz O., Brit N., Gembaruk A. English Language Teaching Methodology: Module 3. Preparing to Teach 2: Student workbook / Pavlo Tychyna Uman state pedagogical university, Faculty of foreign languages. Uman: Vizavy, 2020. 260 p.

3. Core Curriculum English Language Teaching Methodology: School Experience Observation Tasks. Module 3. URL: https://1fd10c7a-6813-41b3-98e8-e5598ca6cc9b.filesusr.com/ugd/15b470_75c5f4ceb 
60d4d2ba30f35f52c2fe5d8.pdf (дата звернення: 24.02.2021).

4. Gembaruk A.S. EFL Teachers Training in Pavlo Tychyna Uman State Pedagogical University: Methodological Aspect. Studies in Comparative Education. 2019. No. 2 (38). P. 70-80.

5. Lee D., Hatesohi, D. Listening: Our most used communication skill. URL: https://mospace.umsystem.edu/ xmlui/bitstream/handle/10355/71861/CM150-1983.pdf?sequence=1 (дата звернення: 24.02.2021).

6. Oxford R. Research update on teaching L2 listening. System. 1993. Vol. 21, No 2. P. $205-211$. URL: http://onlinecourse.ncolctl.org/fundamentals/lesson5/downloads/L5_Oxford.pdf (дата звернення: 24.02.2021).

7. The importance of listening skills in the communication process. URL: https://www.hrdqu.com/ communication-styles/learning-to-listen-the-importance-of-great-communication-skills/ (дата звернення: 24.02.2021).

8. The New Ukrainian School Concept. URL: https://mon.gov.ua/eng/tag/nova-ukrainska-shkola (дата звернення: 21.02.2021). 